\title{
Editorial
}

\section{Marketing and business success}

Over the last year there has been a growing chorus which says that the marketing discipline is in crisis. ${ }^{1}$ The Chartered Institute of Marketing has even launched an independent enquiry into the future of marketing. Critics have pointed to the growth of private label, the decline of brand advertising, the lack of innovations coming from marketing departments, and the increasing tendency of top management to look at non-marketing tools - JIT, bench-marking, reengineering and supply chain management - to garner greater performance. Will marketing retain a core function in the business? Will companies look to other disciplines to deliver their future success?

To examine these issues sensibly one must first define what 'success' is. Second, the major determinants of performance require identification. Finally, how marketing contributes to performance needs to be explored. Only with such a 'model' can these controversial issues about the role and future of marketing be examined.

To all companies success is about profitability and growth. These are measures of financial and marketing competitiveness respectively. What is not often understood, however, is that these are not necessarily correlated; in fact, they often conflict. Measures to boost the long-run share of the brand can easily cut short-term profit. Similarly, boosting short-run profit is often associated with declining long-run marketing competitiveness. Comparing profits across countries reveals an inverse correlation between return on investment and market performance. For example, British companies generally exhibit much higher levels of profitability than those in Japan, yet the latter have exhibited long- run growth, and the former generally declining market shares. Thus the lack of association between marketing investment and profitability is not quite as distressing as it may appear. Branded goods companies can easily boost profits for a few years by cutting back on investment - but is this a sensible decision in the long run?

Performance is really about achieving a balance between market competitiveness and short-run profitability. It is about satisfying shareholders rather than maximising their return. Three factors determine long-run growth and profitability. The critics are correct in that marketing is not essential to long-run or short-run corporate performance. Companies can achieve excellent performance and be quite useless at marketing, although, as will be shown, this is hardly a desirable situation.

The first factor determining performance is the industry that the company is in. Porter has exhibited this clearly in his fiveforces model, 2 in which he showed that industry profitability depends upon entry barriers, competition, the substitutes available, and the strength of both supplier and buyers. For example, of the world's top 15 most profitable companies, ten are pharmaceutical companies. Glaxo, Astra and Merck are much more profitable than Coca Cola, Procter \& Gamble and Unilever, not because they are better at marketing, but because their industry structures are more favourable.

The second determinant of performance is the company's strategic assets. These are advantages derived from a firm's monopolistic position rather than from its superior capabilities. For example, British Airways' profit and growth performance is largely the 
result of it being handed the dominant share of the scarce landing slots at Heathrow, the world's busiest international airport. British Telecom is hugely profitable because of its inherited control of telecommunications networks in the UK. Companies less fortunate in their inheritance of strategic assets do worse, even though they may be better at marketing and all other dimensions of management.

The third determinant of success is the firm's distinctive capabilities. Kay suggests these can be grouped into three categories — innovation skills, reputation and architecture: 3 innovation refers to the company's ability to create new products or marketing concepts; reputation is the value of the firm's brands; architecture means the deeprooted capability of the organisation to forge value-added relationships with customers, suppliers, employees and other organisations. In practice, architecture is the most sustainable of corporate capabilities.

Note that none of these fundamental determinants of corporate success is directly about marketing. However, marketing is crucially important because it permits these industry conditions, strategic assets and distinctive capabilities to be translated into competitive advantage. If the marketing is not right then outstanding capabilities can be wasted in fruitless innovations, powerful strategic assets can be dissipated in inappropriate diversifications, and industry advantages may be unexploited.

How does marketing orientate assets and capabilities to delivering competitive advantage? What are the core marketing tasks today? The most important task is segmentation and positioning - choosing where and how to compete. Companies such as Philips and Hewlett-Packard have time and again thrown away outstanding potential innovations through failure to identify properly target market segments and tailor appropriate brand strategies. Failure to get the marketing right has allowed shrewder competitors like Sony, Matsushita and Amstrad to catch up technically and catapult themselves into market leadership.

The second task of marketing is to guide repositioning strategies. Markets are changing as never before: fashionisation, fragmentation, globalisation, rising expectations for quality, speed and service, are continually eroding current strategies. ${ }^{4}$ The task of marketers is to analyse such changes and to stimulate adaption in the way the company applies its distinctive capabilities. A third and crucial role for marketers is to help build the firm's architecture - the organisational and cultural relationships which are the only long-run way of defending the firm's competitive advantages.

Architecture is about relationships. The core relationship is the partnership between the firm and its customers. But this relationship is founded on the bedrock of other partnerships, one such being the internal relationships between management and employees and among employees, which determine the skills and commitment of the people within the business. Another relationship is the vertical one between the firm and its suppliers and distributors which shape its ability to make added-value offers to customers. For example, it is the architecture of Marks \& Spencer's unique partnerships with its suppliers which explains much of its extraordinarily consistent performance over the years. Finally, and of increasing importance, is the firm's networks: its partnerships with other firms which stretch its capabilities into new technologies and markets. In the future, the real contribution of marketers will be in identifying those relationships which will enhance the firm's long-run competitive advantage. These include partnerships with customers, employees and other firms with complementary skills or strategic assets.

How does this 'model' of corporate success help answer the questions about the future of marketing? First, it is clear that 
success can be achieved without excellence in marketing. The performance of companies or brands like Wellcome, BT, Cable and Wireless and the Financial Times, are examples of this. Similarly, external forces which undermine industry equilibrium and strategic assets will erode performance even when the business has exceptional marketing.

Such factors explain the growth of private label, the relative decline of above-the-line marketing, and the deteriorating rate of innovation in fmcg. These movements are caused by changes in the industry and the environment which have led to increased retailer concentration and a strengthening of the distinctive capabilities possessed by retailers. They have increased buying power and built up the strategic assets of the major multiples. Added to this is the increased fragmentation of markets and media which are eroding both mass brands and mass media. But the critics of marketing have over-focused on fmcg. Outside this area forces are often at work to strengthen brands and the potential of marketing to perform. Microsoft and Intel are two companies benefiting from such trends.

What about the future of head office marketing departments? Marketing will be even more important in the future, but its job is changing and the skills required will be different. Corporate de-layering, the shift away from mass media and the increasing complexity of markets and business func- tions will mean that marketing will decline as a separate function. Marks \& Spencer illustrate the future. Outstanding at marketing, it has never had a marketing department or a marketing director. Marketing is regarded as being too important to be left to a specialist department. The real marketing tasks are forging internal and external relationships and networks which will add value for customers. Top managers will increasingly be team players creating customercentred partnerships which transcend functional lines.

\section{Peter Doyle University of Warwick}

\section{References}

(1) Brady, J. \& Davis, I. (1993) 'Marketing's Mid-Life Crisis', McKinsey Quarterly, No. 2, pp. 17-29.

(2) Porter, M.E. (1980) 'Competitive Strategy: Techniques for Analysing Industries and Competitors', New York, The Free Press.

(3) Kay, J. (1993) 'Foundations of Corporate Success', Oxford, Oxford University Press.

(4) Doyle, P. (1994)` Marketing Management and Strategy', Hemel Hempstead, Prentice-Hall International. 